\title{
FTIR and HPLC-Based Metabolomics of Yacon Leaves Extracts (Smallanthus sonchifolius [Poepp \& Endl.] H. Robinson) from Two Locations in Indonesia
}

\author{
Zuhelmi Aziz ${ }^{1}$, Nancy Dewi Yuliana ${ }^{2, *}$, Partomuan Simanjuntak ${ }^{3}$, Mohamad Rafi $^{4}$, and Syamsudin ${ }^{1}$ \\ ${ }^{1}$ Doctoral Program of Pharmacy Faculty, University of Pancasila, Srengseng Sawah Jagakarsa, Jakarta Selatan 12640, Indonesia \\ ${ }^{2}$ Department of Food Science and Technology, Faculty of Agricultural Technology, Bogor Agricultural University, \\ Tanjung Street, IPB Dramaga Campus, Bogor 16680, Indonesia \\ ${ }^{3}$ Research Center for Biotechnology, Indonesian Institute of Sciences (LIPI), Jl. Raya Bogor Km 46, Cibinong 16911, Indonesia \\ ${ }^{4}$ Department of Chemistry, Faculty of Mathematics and Natural Sciences, Bogor Agricultural University, \\ Tanjung Street, IPB Dramaga Campus, Bogor 16680, Indonesia
}

* Corresponding author:

tel: $+62-81380035660$

email:nancy_dewi@ipb.ac.id

Received: February 7, 2019

Accepted: July 31, 2019

DOI: $10.22146 /$ ijc. 43453

\begin{abstract}
Smallanthus sonchifolius [Poepp. \& Endl.] H. Robinson (Asteraceae) also known as Yacon or insulin plant, is traditionally used for treating diabetes. Varying geographical origins and postharvest handling, however, seem to affect quantitative and qualitative metabolites in the leaves of Smallanthus sonchifolius [Poepp. \& Endl.] $H$. Robinson (Yacon). This study was conducted to compare and differentiate metabolites profile/fingerprint of Yacon leaves which were grown and obtained from different locations in Pulau Jawa i.e. Lembang (Jawa Barat) and Wonosobo (Jawa Tengah). Three different solvents (95\% ethanol, 50\% ethanol and water) were used to obtain Yacon leaves extracts, in order to determine the suitable solvent to produce discernable differentiation through FTIR and HPLC-based metabolomics. Principal Component Analysis (PCA) of FTIR data (4000-400 $\mathrm{cm}^{-1}$ wavenumber) indicated that Yacon leaves extracted with 95\% ethanol, had a distinctive FTIR fingerprint profile when compared to others. However, the FTIR-based PCA could not differentiate the extracts based on their geographical origins, although PCA analysis of HPLC-data successfully differentiated the extracts based on their geographical origins. Furthermore, the prominent peak for the leaves extract from Lembang and Wonosobo as regards to retention time, was observed at 21.59-25.10 $\mathrm{min}$ and 20.69-21.695 min respectively. Notably, $R^{2} Y$ and $Q^{2}$ values obtained by cross-validation and permutation tests showed all multivariate models were statistically reliable. Overall, there is a need to conduct further research using a more sophisticated tool such as LC-MS, to identify which metabolites were represented by the aforementioned FTIR and HPLC data.
\end{abstract}

Keywords: FTIR; HPLC; metabolomics; Smallanthus sonchifolius; Yacon

\section{- INTRODUCTION}

Smallanthus sonchifolius [Poepp. \& Endl.] $\mathrm{H}$. Robinson or Yacon is a perennial plant from the native Asteraceae family, located in the Andean regions of South America, spanning from Colombia to Argentina. This globally cultivated plant is also found in Europe, New Zealand and even Asia (Japan and Indonesia) [1]. Cultivated in Lembang, Jawa Barat Province, and in
Wonosobo, Jawa Tengah Province; Yacon has been widely used as a traditional medicine to treat diabetes in Indonesia. Currently, its leaves are widely used as herbal medicine to also treat diabetes, often administered in the form of a single simplicia or mixed with other simplicia in the form of capsules or teabags.

The presence of phenolic constituents in Yacon has been linked to its antidiabetic (hypoglycaemic) and antihypertensive effects [2]. Studies by numerous researchers 
have also reported its anti-inflammatory capacity, observed through metabolomics profiling of its compounds [3], and antidiabetic activity through $\alpha$-glucosidase inhibition [4]. Despite several studies on the phytochemical content of Yacon, there have not been any reports on comparison and differentiation of Yacon metabolites profile, grown and obtained from different locations in Pulau Jawa. Such comparison and differentiation are necessary to ensure the quality of the potential effects that have been mentioned above, as the possibility of investigating and proving chemical variation as a result of geographical differences, may also have the potential within the field of pharmaco-botany, towards achieving optimal growth of Yacon to exhibit certain desired potency.

Previous phytochemical research of Yacon leaves has shown it contains sesquiterpene lactones such as sonchifolin, uvedalin, enhydrin, fluctuanin, polymatin B, fluctuadin, and polymatin $\mathrm{C}$, and along with melampolide compounds [5]. Further analysis showed flavonoid compounds such as quercetin [6], polyphenolic compounds such as chlorogenic acid, ferulic acid, and caffeic acid derivatives such as 1.5-O-di-caffeoylquinic acid (1,5-CQA), 4,5-O-di-caffeoylquinic acid (4,5-CQA), and 3,5-O-di-caffeoylquinic acid (3,5-CQA) [7]. The reported caffeic acid derivative compounds were reported to have strong antioxidant properties, capable of blood glucose reduction through inhibition of the a-glucosidase enzyme. In addition, enhydrin has been observed in the increase of $\beta$-pancreatic cells in streptozotocin (STZ)induced diabetogenic mouse pancreatic cells [5].

Currently, quality control of raw materials for herbal medicine is commonly performed through organoleptic evaluation, although scientific laboratories deem it comprehensively inadequate, as it relies simply on the subjective sensory evaluation of limited pool of experts. Furthermore, organoleptic tests have been shown to possess significant weaknesses and limitations, due to some sensory traits that cannot be described [8]. Hence edge-cutting instruments used within the field of analytical chemistry shows promise to devise a method for mentioned quality control using analytical instruments. Among these analytical instruments includes FTIR spectroscopy and HPLC, which is easy to use, cheap and fast when investigating samples $[9,11]$. These instruments fulfilling efficient analysis criteria are also capable of investigating several components simultaneously, without damaging the samples $[9,11]$.

The FTIR method produces a spectrum that provides complex data, which can be used to thoroughly describe the chemical characteristics of a sample [9]. Although IR spectrum pattern complexity is visually difficult to be interpreted, chemometrics method can be used to resolve this problem [10]. Juliani in his study used FTIR-based metabolomics, to identify an active compound with a-glucosidase inhibitory and antioxidant properties in aerial parts of Orthosiphon stamineus (OS) extract and its fractions [9]. Another option is using the HPLC method which produces chromatogram, illustrating the overall content and estimation of each content within a sample, based on the percent area of significant peaks. Ascertaining this capability, Feng et al. showed the potential of pairing HPLC with chemometric methods in order to analyze, obtain fingerprint and recognize the chemical pattern of ginger obtained from different markets in China [11].

In this study, we proposed to compare and differentiate metabolites profile/fingerprint of Yacon leaves grown and obtained from different locations in Pulau Jawa i.e. Lembang (Jawa Barat) and Wonosobo (Jawa Tengah). Three different solvents (95\% ethanol, $50 \%$ ethanol and water) were used to make Yacon leaves extracts, in order to determine the suitable solvent to produce discernable differentiation through FTIR-based and HPLC-based metabolomics. It was assumed that the different condition between the two (2) locations and three (3) extraction solvents, would result in significant variations and levels of the chemical content in Yacon leaves, which would further affect the fluctuation of its bioactivity. This sought out differences, is targeted at improving the quality control of raw material for Yacon herbal products.

\section{- EXPERIMENTAL SECTION}

\section{Materials}

Yacon leaves were collected from Perkebunan Najwa Herbal in Wonosobo, Jawa Tengah (J) and Perkebunan 
Manoko in Lembang, Jawa Barat (B). Ethanol, acetonitrile (HPLC grade), and formic acid were purchased from Merck, Darmstadt, Germany. While potassium bromide for spectroscopy was purchased from Sigma Aldrich, St. Louis, USA.

\section{Instrumentation}

This study utilized an array of instruments which includes Sartorius TE214S analytical balance (Sartorius, Göttingen, Germany), ultrasonic LC 30 H Elma (Elma Schmidbauer Gmbh, Gottlieb-Daimler Straß 17 78224, Singen, Germany), FTIR spectrophotometer Tensor 37 (Bruker) equipped with OPUS software and HPLC LC-20 AD (Shimadzu, Kyoto, Japan).

\section{Procedure}

\section{Sample preparation and extraction}

The Yacon leaves were dried, grinded and sieved with a 40 mesh sieve. Approximately $20 \mathrm{~g}$ of Yacon leaves powder was extracted using $100 \mathrm{~mL}$ of $95 \%$ ethanol, after-which the extract was collected from the filtered mixture. The residue was extracted twice by ultrasonication for $30 \mathrm{~min}$ using $\pm 50 \mathrm{~mL}$ of $95 \%$ ethanol, which brought the total volume of solvents used to $200 \mathrm{~mL}$. All of the extracts were pooled, while the residual solvent was evaporated using a vacuum rotary evaporator, after-which the extract was then dried using the freeze dryer. Similarly, the same procedure was repeated for $50 \%$ ethanol and water. Ten replications were made so 60 fractions were obtained. The resulted extracts were named according to the origin, extraction solvent and replicate numbers, for examples: B91 = Yacon from Lembang extracted with 95\% ethanol replication 1, JW1 = Yacon from Wonosobo extracted with water replication 2.

\section{Measurement of FTIR spectrum}

The FTIR spectrum was obtained from each extract, with two (2) measurements approximately $2 \mathrm{mg}$ of each Yacon leaves extract, mixed homogeneously with $0.2 \mathrm{~g}$ of potassium bromide, further pressed to form a tablet. Using OPUS 4.2 software (Bruker Optik GmbH, Karlsruhe, Germany), the FTIR spectrum was measured in the region of $4000-400 \mathrm{~cm}^{-1}$.

\section{HPLC analysis}

HPLC analysis was conducted as follows: C18 stationary phase, UV detector $254 \mathrm{~nm}, 1 \mathrm{~mL} / \mathrm{min}$ flowrate; $20 \mu \mathrm{L}$ injection volume with gradient elution technique using mobile phase composition which was from $0-5 \min (\mathrm{ACN} 15 \%), 5-15 \mathrm{~min}(\mathrm{ACN} 15-50 \%)$, 15-30 min (ACN 50-70\%), 30-45 min (ACN 70-85\%), and 45-60 $\mathrm{min}$ (ACN 85-95\%) with a flowrate of $1 \mathrm{~mL} / \mathrm{min}$ with an analysis time of $60 \mathrm{~min}$. The waters column, columns $\times$ bride, dimensions were $(4.6 \mathrm{~mm} \times$ $150 \mathrm{~mm} \times 5 \mu \mathrm{m}$ ), which was obtained from Waters Corporation, 34 Maple Street, Milford, Massachusetts, USA.

\section{Data pre-processing treatments}

The quantified chromatogram was categorized into variables based on its length and was pre-processed in four (4) steps to produce clear differentiation result. Firstly, the exclusion of variables which had a value of 0 was observed on at least $50 \%$ of the samples, either globally or locally within a group of samples, with further censoring of outliers through $90 \%$ winsorization. Secondly, the normality test was performed using four (4) different methods which include Shapiro-Wilk, Anderson-Darling, Lilliefors, and Jarque-Bera to evaluate the goodness of fit of the samples. Thirdly, comparison of variance using Levene's test and Bartlett's test to justify the relevance of PCA. Lastly, the KaiserMeyer-Olkin Test for Sampling Adequacy to determine whether the data obtained from quantified chromatogram was sufficient for factor analysis. Notably, these aforementioned tests were conducted using XLSTAT version 2014.5.03.

\section{Principal component analysis (PCA)}

PCA was done using SIMCA-P version 14 (Sartorius Stedim Biotech, Umea, Sweden), producing score plots, which was used to examine whether the sample groups were in accordance with their solvents and geographical origins. PCA investigation was conducted towards the absorption over certain ranges of wavelengths, while data as regards to the extracts with different solvents were obtained from quantification of FTIR spectra. Further PCA was performed on peak retention time and percentage of peak area $(\% \mathrm{~A})$, as regards to the data obtained from quantification of 
HPLC chromatograms. Notably, PCA also produces fingerprints of location origin and solvent, obtained from unique values of absorbance at certain wave numbers for certain extracts (FTIR), or from the unique percent area value $(\% \mathrm{~A})$ at certain peak retention times for certain extracts (HPLC). PCA analysis for FTIR and HPLC data was done by using pareto scaling method. FTIR data had 60 observations and 1866 independent variables (FTIR wave numbers), while HPLC data had 60 observations and 31 independent variables (HPLC retention time).

\section{- RESULTS AND DISCUSSION}

\section{FTIR Spectra of Yacon Leaves Extracts}

FTIR spectra were used to single out a functional group from the chemicals in the plant extract, which was made in the mid-infrared region $\left(4000-400 \mathrm{~cm}^{-1}\right)$. A representative of the FTIR spectrum is obtained from different samples of Yacon leaves, in the mentioned infrared region observed in Fig. 1.

Results from the FTIR spectra indicated that samples from both regions, which were extracted using a similar solvent, showed a similar spectral pattern qualitatively albeit different values of absorption intensity. Therefore, it was concluded that direct qualitative observation towards the spectra was not adequate to reveal the difference in geographical origins of the plant and any other inference towards the variation of the chemical composition of the samples.

Although direct qualitative observation failed to reveal the variation resulted from different geographical origins of the plant, variation resulting from different solvents was observed qualitatively on the spectra of samples from one region. Therefore it was assumed the variation as a result of the interactions between different solvents occurred because of the varying amount of the metabolite compounds, within the samples extracted with different solvents.

Visually, the spectrum of $95 \%$ ethanol extracts was sharper than the spectrum of $50 \%$ ethanol extract, and the spectrum of water extract inclusively (Fig. 1). Further comparison resulted in some typical absorbance peaks within the range of $3367-3391 \mathrm{~cm}^{-1}$, indicating the absorption of the hydroxyl group $(-\mathrm{OH})$, although the absorbance peaks within the range of $2925-2932 \mathrm{~cm}^{-1}$ and around $2851 \mathrm{~cm}^{-1}$ demonstrated the absorption of the functional groups - $\mathrm{CH}$ stretching. Notably, the absorbance peaks around 1689, 1721 and $1740 \mathrm{~cm}^{-1}$ denoted the absorption of the carbonyl functional group,

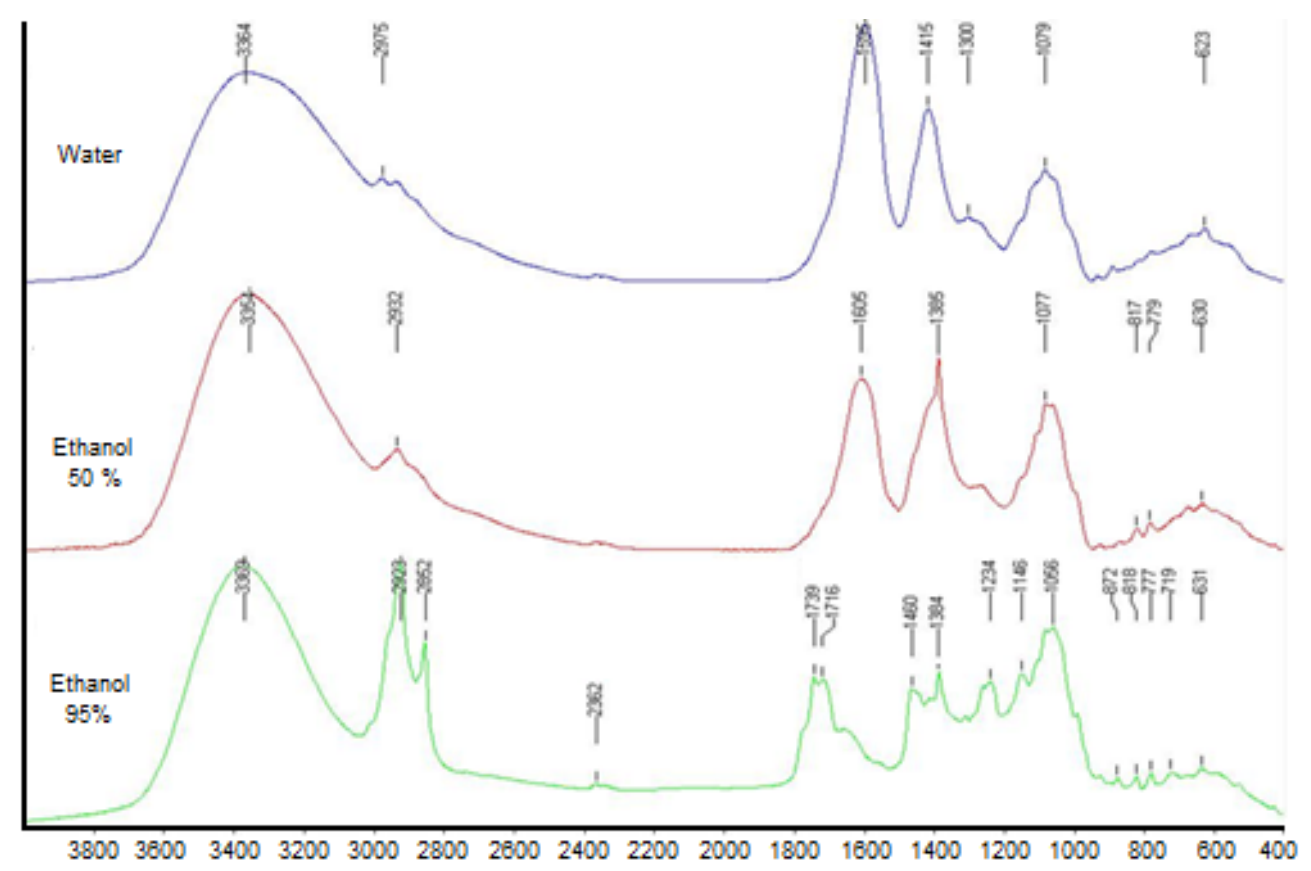

Fig 1. Example of FTIR-spectra of extracts of Yacon leaves, obtained from Jawa Tengah (J) in the range of 4000$400 \mathrm{~cm}^{-1}$ wavenumbers 
while peaks around $1384 \mathrm{~cm}^{-1}$ indicated the presence of the methyl group $\left(-\mathrm{CH}_{3}\right)$. Furthermore, absorbance peaks within the range of $1250-1020 \mathrm{~cm}^{-1}$ were marked by the absorption of aliphatic amine functional group $(\mathrm{C}-\mathrm{N}$ stretching), while the peaks within the range of $1000-$ $650 \mathrm{~cm}^{-1}$ could be seen through the absorption of alkenes functional group $\mathrm{C}-\mathrm{H}$ bend [12]. Lastly, in all spectral samples obtained, the absorbance peaks shown around $2300 \mathrm{~cm}^{-1}$ was possibly due to $\mathrm{CO}_{2}$ uptake from the air.

The complexity of the mentioned FTIR spectra was the result of various constituents of chemical compounds present within the samples. This noted complexity contributed towards the difficulty of making any direct visual interpretation, as the quantified FTIR spectra and the absorbance for each wave number was further analyzed using chemometric methods.

\section{PCA of FTIR-Data}

The quantified FTIR absorbance of Yacon leaves extract samples for each wave number, was used as input for PCA which was then transformed into a set of values of linearly uncorrelated variables called principal components (PCs) [13]. The observed transformation was conducted to investigate the geographical origins of each sample and the solvents used for extractions. Subjecting the quantified FTIR spectra to data pre-processing, resulted in the elimination of variables in which at least $50 \%$ of them were 0 , further winsorizing the outliers. The pre-processing also significantly showed that the quantified FTIR spectra were distributed normally with at least one sample group, where its variance significantly differed compared to other groups. The PCA model resulted in 4 components which explain 91.7\% total variations where the value of $\mathrm{Q}^{2}$ was recorded at 0.894 , indicating that the transformation was reliable.

As shown by the PCA score plot (Fig. 2), the samples didn't display any remarkable differences, as there was no significant distinction between samples obtained from different regions. However, samples extracted using different solvents could be discerned into distinct groups (Fig. 3). The resulting distribution plot could be used to interpret the separation of samples respectively to their solvent, estimated by observing the centroids packing of each sample groups to each other. Explicitly, distribution plots which represented sample J extracted with three different solvents showed that they were significantly different from each other (Fig. 4).

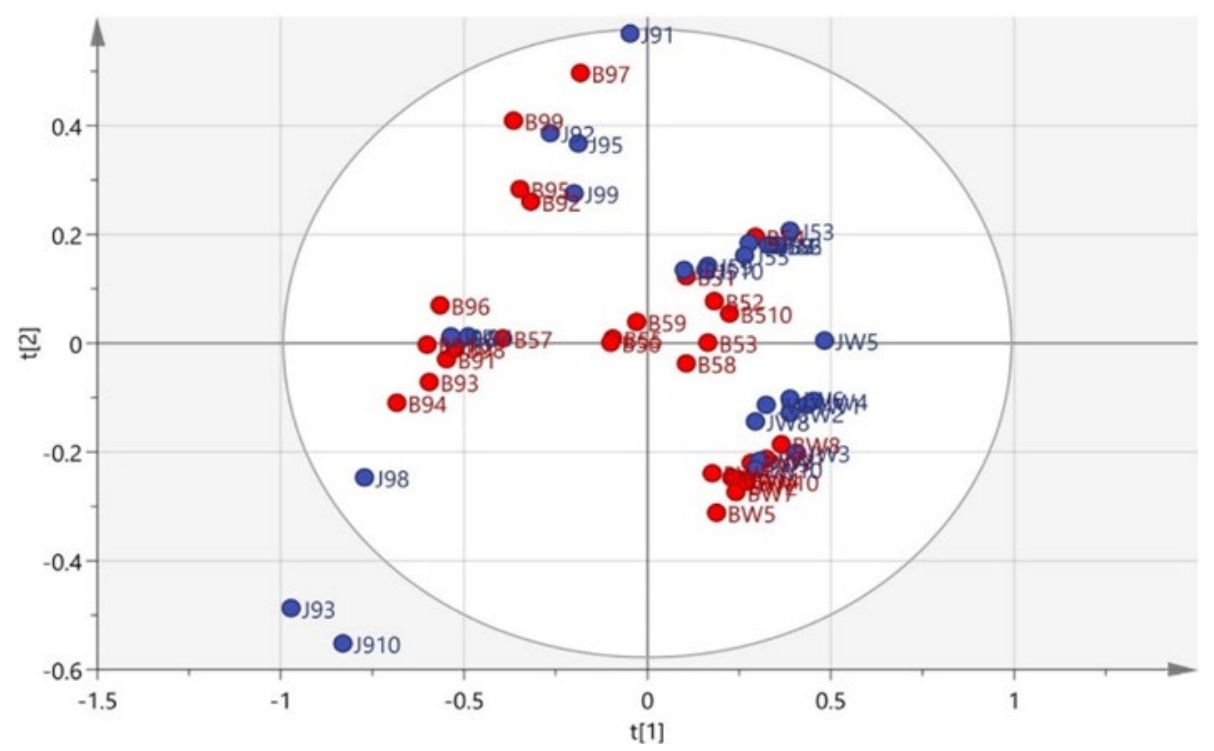

Fig 2. Geographical-origin-based PCA Score Plot of FTIR-data of Yacon leaves based on Pareto scaling (3800-400 $\left.\mathrm{cm}^{-1}\right)$. Geographical origins denoted by color. Blue for Jawa Barat (B) and red for Jawa Tengah (J). For label explanation see Method section. $\mathrm{R}^{2} \mathrm{X}$ cumulative $=0.956$ and $\mathrm{Q}^{2}=0.932$ 


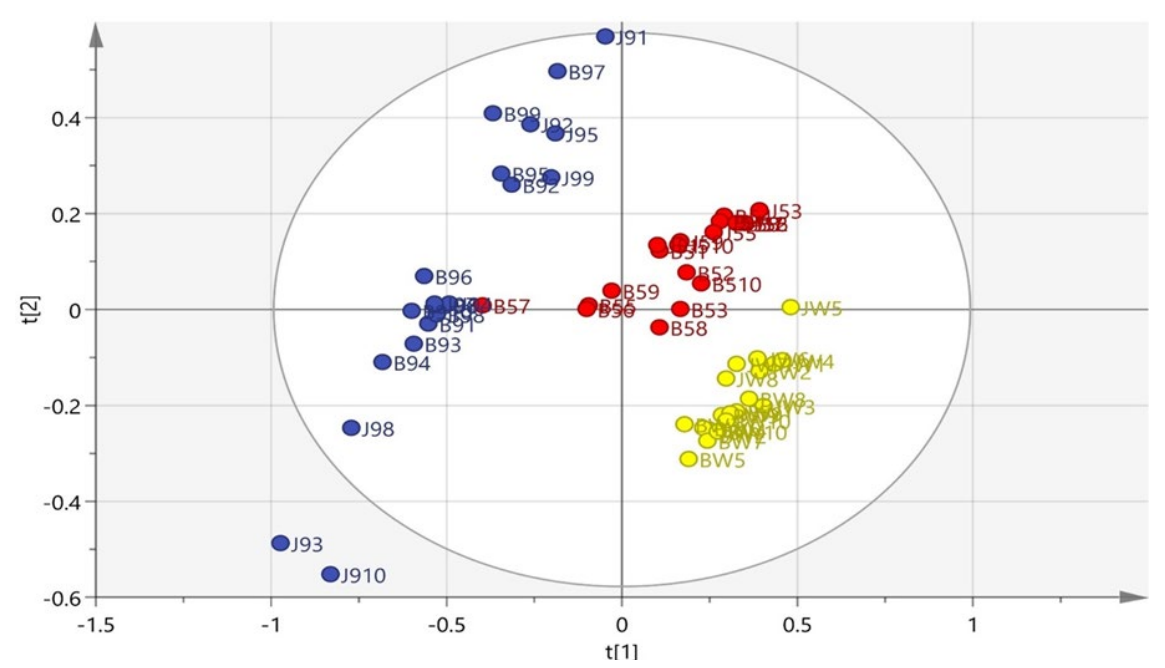

Fig 3. Solvent-based PCA Score Plot of FTIR-data of Yacon leaves based on Pareto scaling $\left(3800-400 \mathrm{~cm}^{-1}\right)$. Solvents denoted by color. Yellow for water, blue for ethanol $50 \%$, and red for $95 \%$ ethanol. $\mathrm{R}^{2} \mathrm{X}$ cumulative $=0.917$, $\mathrm{Q}^{2}=0.894$
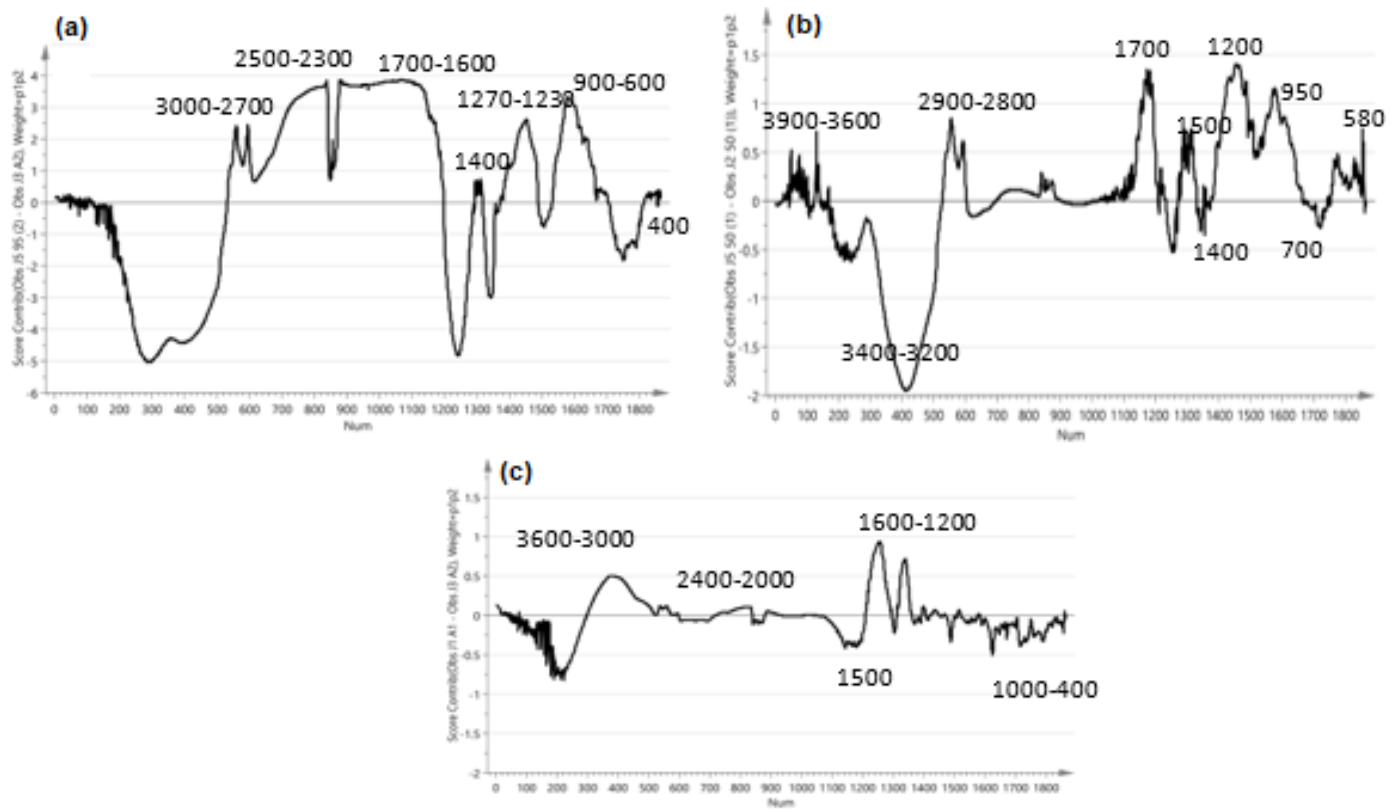

Fig 4. Representatives of PCA contribution plot of FTIR-data of Yacon leaves from Wonosobo (Jawa Tengah). (a) Yacon 95\% ethanol extract, (b) Yacon $50 \%$ ethanol extract, (c) Yacon water extract. In each contribution plots, the wave numbers positioned above the $\mathrm{X}$-axis were present at a higher intensity at the respective extract as compared to those positioned below the $\mathrm{X}$-axis

The 95\% ethanol extract samples (Fig. 4(a)) showed a higher absorbance in an area within the range of 2700$1700 \mathrm{~cm}^{-1}$, which was interpreted as having higher absorption of hydroxyl group from acid $(\mathrm{OH}$ within the range $\left.2500-2700 \mathrm{~cm}^{-1}\right)$, alkanes $(\mathrm{C}-\mathrm{H}$, within the range of 2850-3000 $\left.\mathrm{cm}^{-1}\right)$, C-H stretching (1450-1470) and carbonyl functional group $(\mathrm{C}=\mathrm{O})$ from aldehyde/ketone/carboxylic acids $\left(1675-1740 \mathrm{~cm}^{-1}\right)$ and -C-O-C from ether (1230-1270). Meanwhile, 50\% of ethanol extract samples showed lower absorbance within the range of $1700-400 \mathrm{~cm}^{-1}$, indicating the presence of the methyl group $\left(-\mathrm{CH}_{3}\right.$ within the range of 
$1470-1340 \mathrm{~cm}^{-1}$ ), alkenes (C-H within the range of 995$\left.675 \mathrm{~cm}^{-1}\right), \mathrm{C}-\mathrm{O}$ functional group of alcohol, ether, carboxylic acids and esters [12], as compared to other groups. This finding resonates to numerous findings as regards to $50 \%$ ethanol extract samples (Fig. 4(b)) resembling 95\% ethanol extract samples, except within the wavenumber range of $1700-1500 \mathrm{~cm}^{-1}$ which can be attributed to the absorption of primary and secondary amines functional group $\mathrm{N}-\mathrm{H}$, amines bending (1575$\left.1650 \mathrm{~cm}^{-1}\right) \mathrm{C}=\mathrm{N}$ : imines, oxime $\left(1640-1690 \mathrm{~cm}^{-1}\right), \mathrm{C}=\mathrm{O}$ : amides (1640-1670 $\mathrm{cm}^{-1}$ ) and within the range of 2853$2929 \mathrm{~cm}^{-1}$. However, the 50\% ethanol extract showed lower absorption of alkanes functional group $\mathrm{C}-\mathrm{H}$ stretching, compared to $95 \%$ ethanol extract samples. Notably, water extract samples (Fig. 4(c)) also demonstrated the lowest absorption on the abovementioned ranges.

The unique profiles of IR absorption could then be concluded from the fingerprints that differ the samples based on the solvents. Specifically, Fig. 4 shows functional groups present in the area as follows; $-\mathrm{CH} 3, \mathrm{C}-\mathrm{H}, \mathrm{C}=\mathrm{C}-\mathrm{H}$, $\mathrm{C}-\mathrm{O}$ and $\mathrm{C}-\mathrm{C}$, with the functional group predominantly present in the water extract.

PCA loading plot comprehensively illustrates absorbance intensities, which were used to cluster samples (Fig. 5). It was indicated that absorption at 3600$3000 \mathrm{~cm}^{-1}$ of $\mathrm{C}-\mathrm{H}$ stretching, free $\mathrm{O}-\mathrm{H}$ stretching, $\mathrm{O}-\mathrm{H}$ stretching, and $\mathrm{N}-\mathrm{H}$ stretching; at $1700-1500 \mathrm{~cm}^{-1}$ of $\mathrm{C}=\mathrm{C}$,
$1500-1300 \mathrm{~cm}^{-1} \mathrm{C}-\mathrm{O}-\mathrm{C}$ asymmetric stretching, $\mathrm{C}-\mathrm{O}$ stretching; and at $700-540 \mathrm{~cm}^{-1}$ of $\mathrm{C}-\mathrm{H}$ bending and CO stretching were dominantly present in $95 \%$ ethanol extract. While at $3000-2800$ and $2700-2400 \mathrm{~cm}^{-1}$ of O-H stretching, $1300-700 \mathrm{~cm}^{-1}$ of $\mathrm{C}-\mathrm{O}$ stretching, $\mathrm{C}-\mathrm{H}$ stretching and bending, with $540-400 \mathrm{~cm}^{-1}$ of C-C skeletal vibration dominated the water and $50 \%$ ethanol extract.

\section{PCA of HPLC-Data}

HPLC chromatogram profiles of the Yacon leaves extracts from sample B and J (Fig. 6), shows similarities with the following details; 36 peaks were detected in each chromatogram extract, however in 50\% ethanol extract and 95\% Yacon B, peak numbers: 5 and 30 (P5 and P30) were detected with an area value of $0.000 \%$. Notably, the similarities and number of peaks made the chromatogram profiles difficult to be distinguished visually. Hence, further investigation was conducted using PCA to differentiate the profiles of the samples.

The quantified chromatograms were subjected to data pre-processing and PCA, similar to FTIR-spectra. The resulting PCA had 3 components and captured $85 \%$ variations with $\mathrm{Q}^{2}$ value at 0.68 , which showed that the transformation was reliable. As illustrated by the PCA score plot (Fig. 7), samples could be distinguished based on the geographical origins and solvents used (Fig. 8). PCA biplot (Fig. 9) showed that the peaks were correlated with the geographical origin clusters, as samples

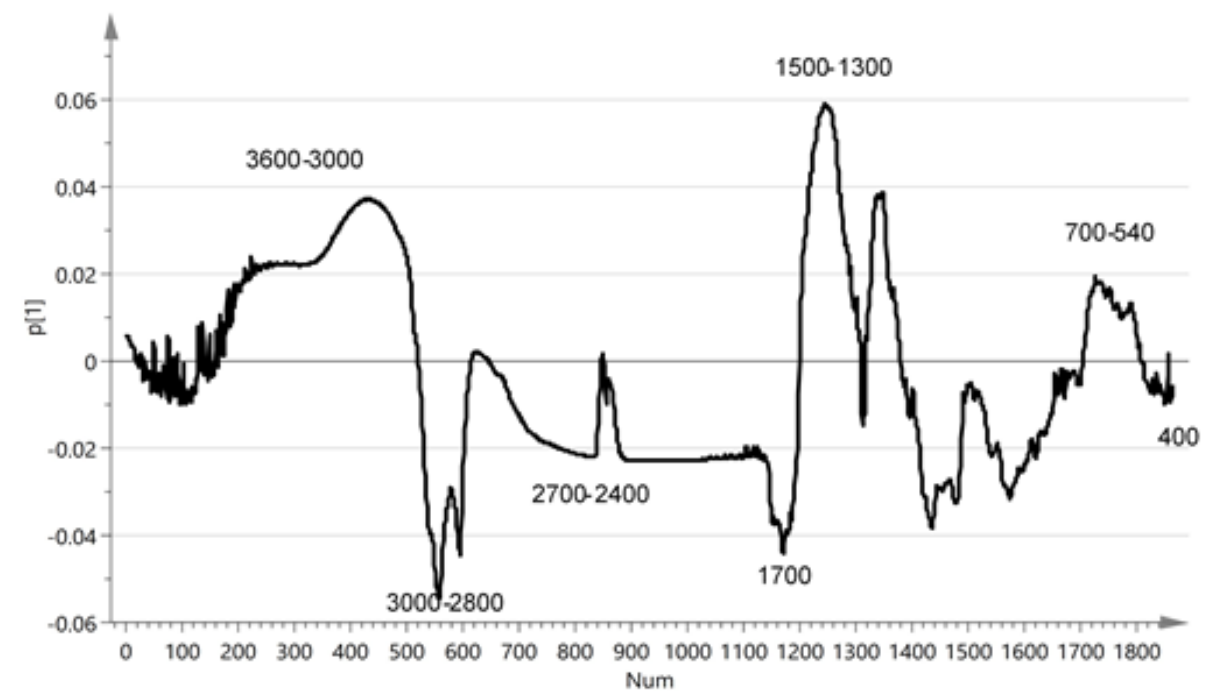

Fig 5. PCA loading line plot of FTIR data of Yacon extract obtained from different solvent extraction 

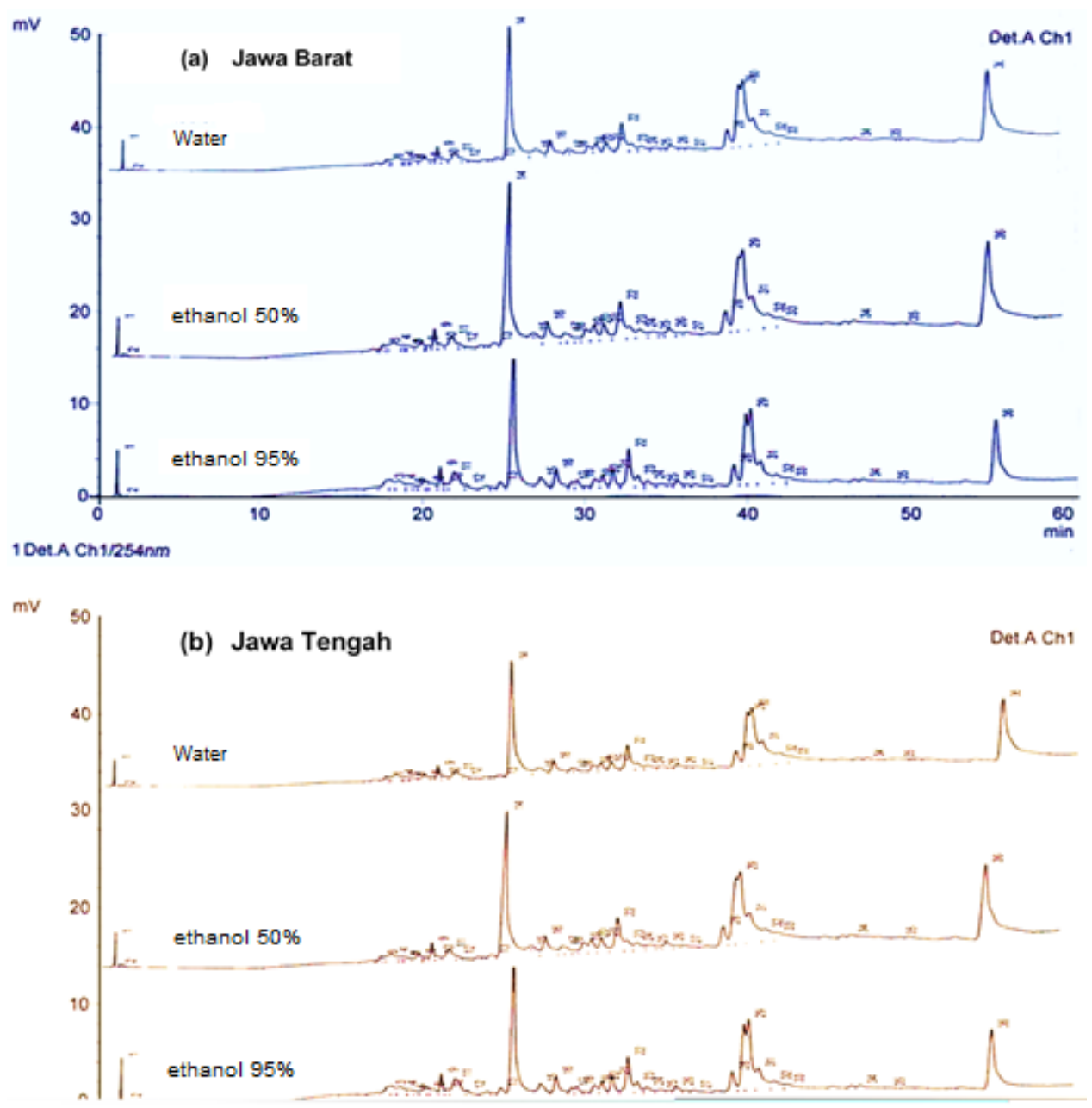

Fig 6. Example of HPLC- chromatograms of extracts of Yacon leaves from Lembang-Jawa Barat (a) and from Wonosobo-Jawa Tengah (b)

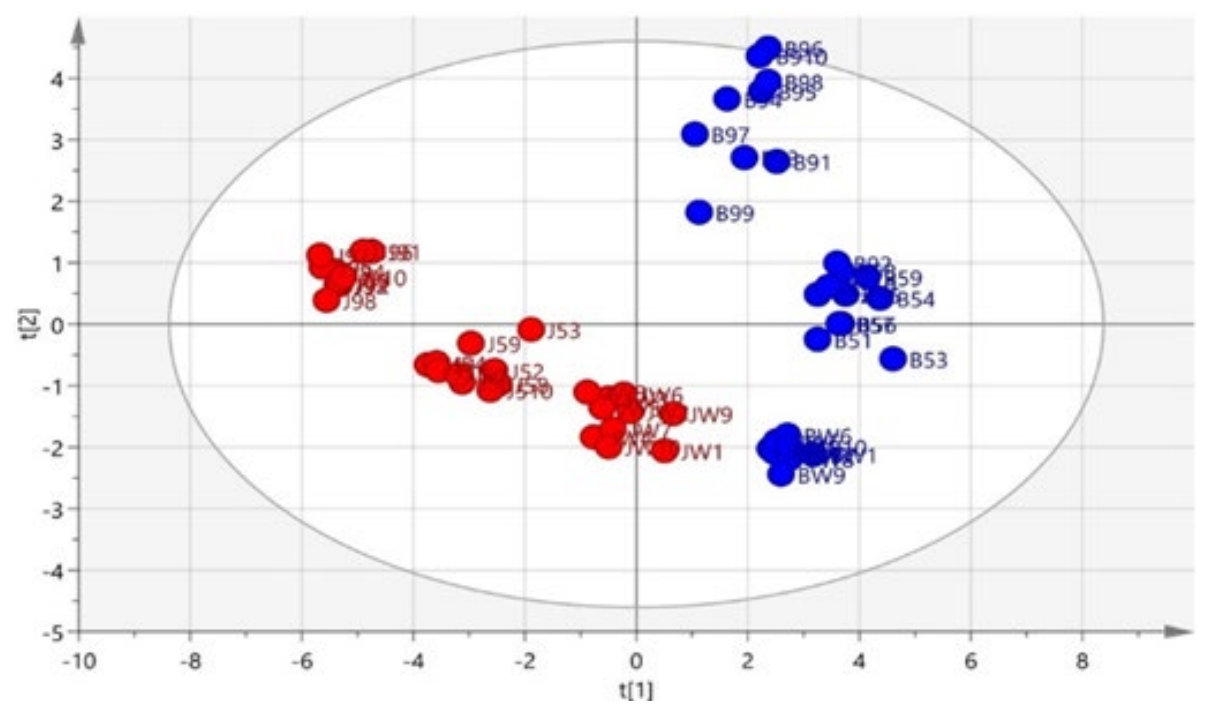

Fig 7. Geographical-origin-based PCA Score Plot of HPLC-data of Yacon leaves. Geographical origins denoted by color. Blue for Lembang-Jawa Barat (B) and red for Wonosobo-Jawa Tengah (J). $\mathrm{R}^{2} \mathrm{X}$ cumulative $=0.85$ and $\mathrm{Q}^{2}=0.68$ 


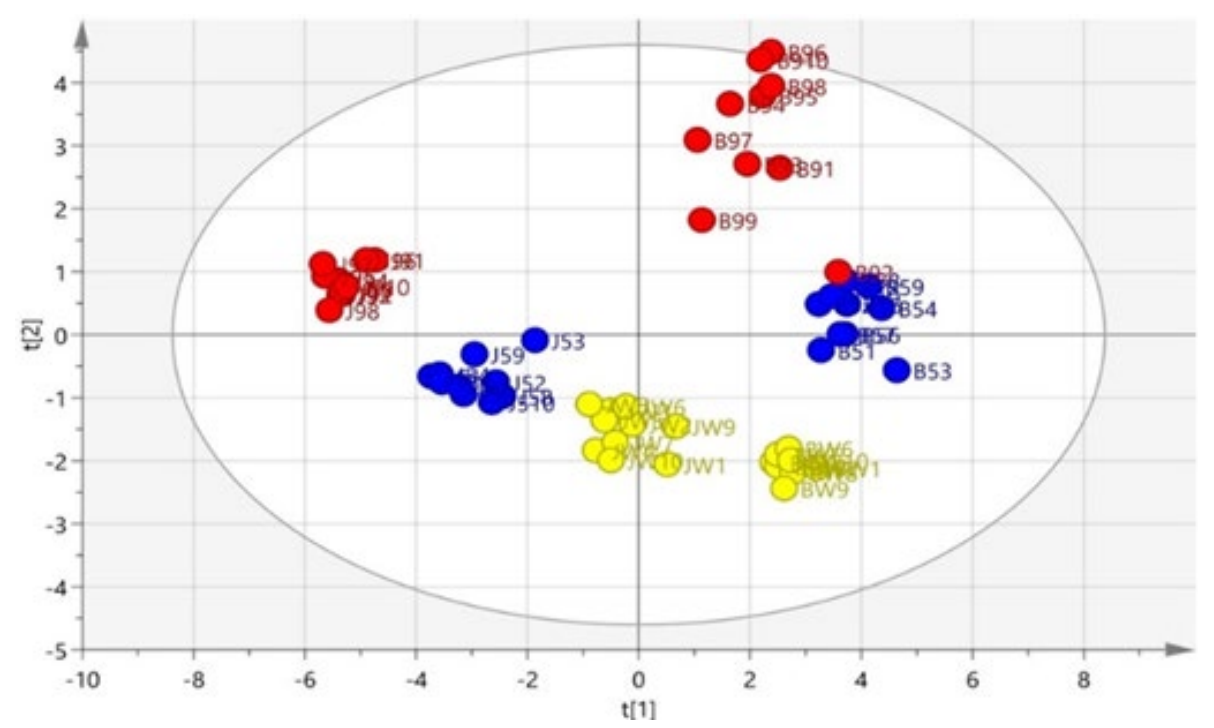

Fig 8. PCA score plot HPLC data of Yacon leaves extract colored in accordance with their extraction solvent, Blue $=$ water extract; Red $=$ ethanol 50\% extract and Yellow $=$ ethanol 95\% extract

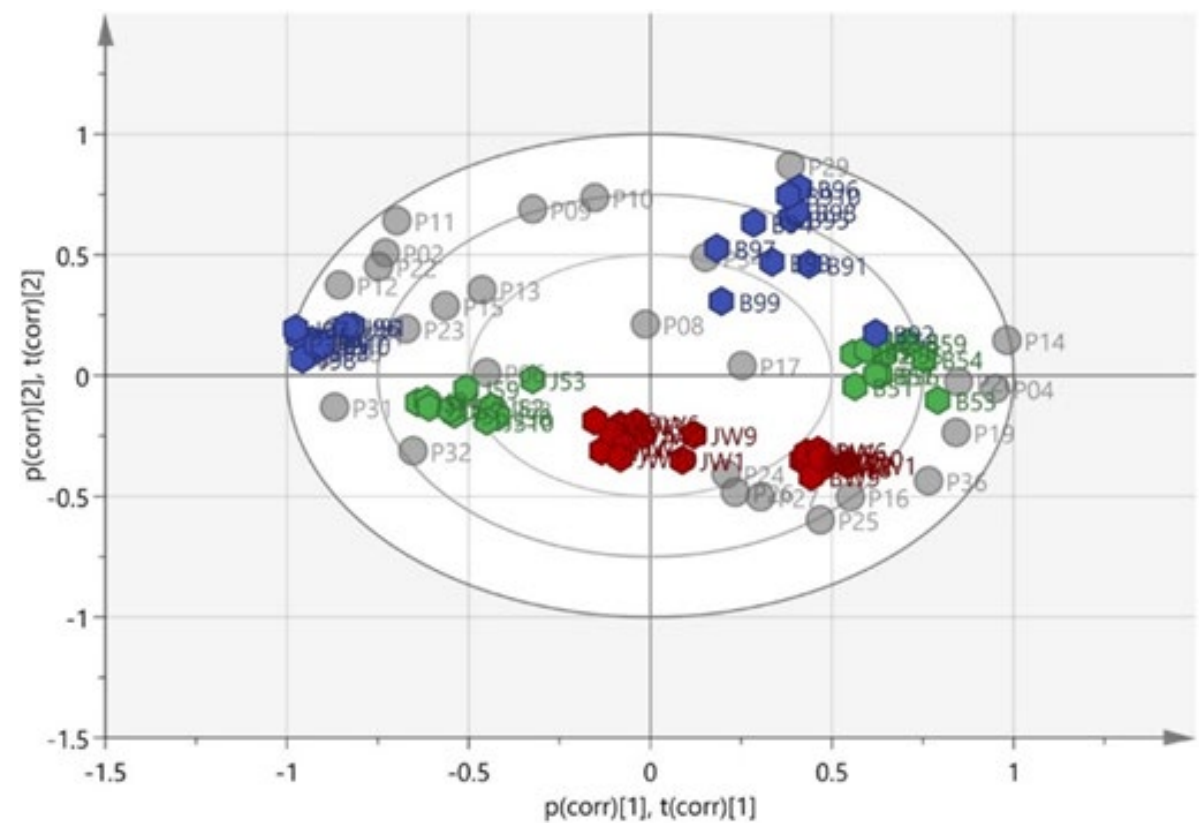

Fig 9. PCA loading biplot HPLC data of Yacon extract based on location origin. Blue = Yacon B (Lembang, Jawa Barat), purple $=$ Yacon $\mathrm{J}$ (Wonosobo, Jawa Tengah), grey circle $=$ peak number of the related retention time peak $(\mathrm{P})$. The retention times abundantly found in particular extract were located nearby the associated extracts. For example, P32 (Peak no. 32) had high intensity in ethanol 50\% extract

from Jawa Barat (B) were positively characterized by peak 04, peak 09 and peak 14.

Further analysis was conducted on water extracts from both regions (Fig. 10), by studying the contribution plot. Compared to overall samples, Yacon B water extract (BW) mainly exhibited higher intensities on peak 14, peak
16 and peak 36, with lower intensities at peak 11 and peak 29. Similarly, compared to overall samples, Yacon J water extract (JW) demonstrated lower intensities on peak 15 and peak 16, with higher intensity on peak 36 .

In this preliminary study, we used FTIR and HPLC, thus the provided information is rather limited. 

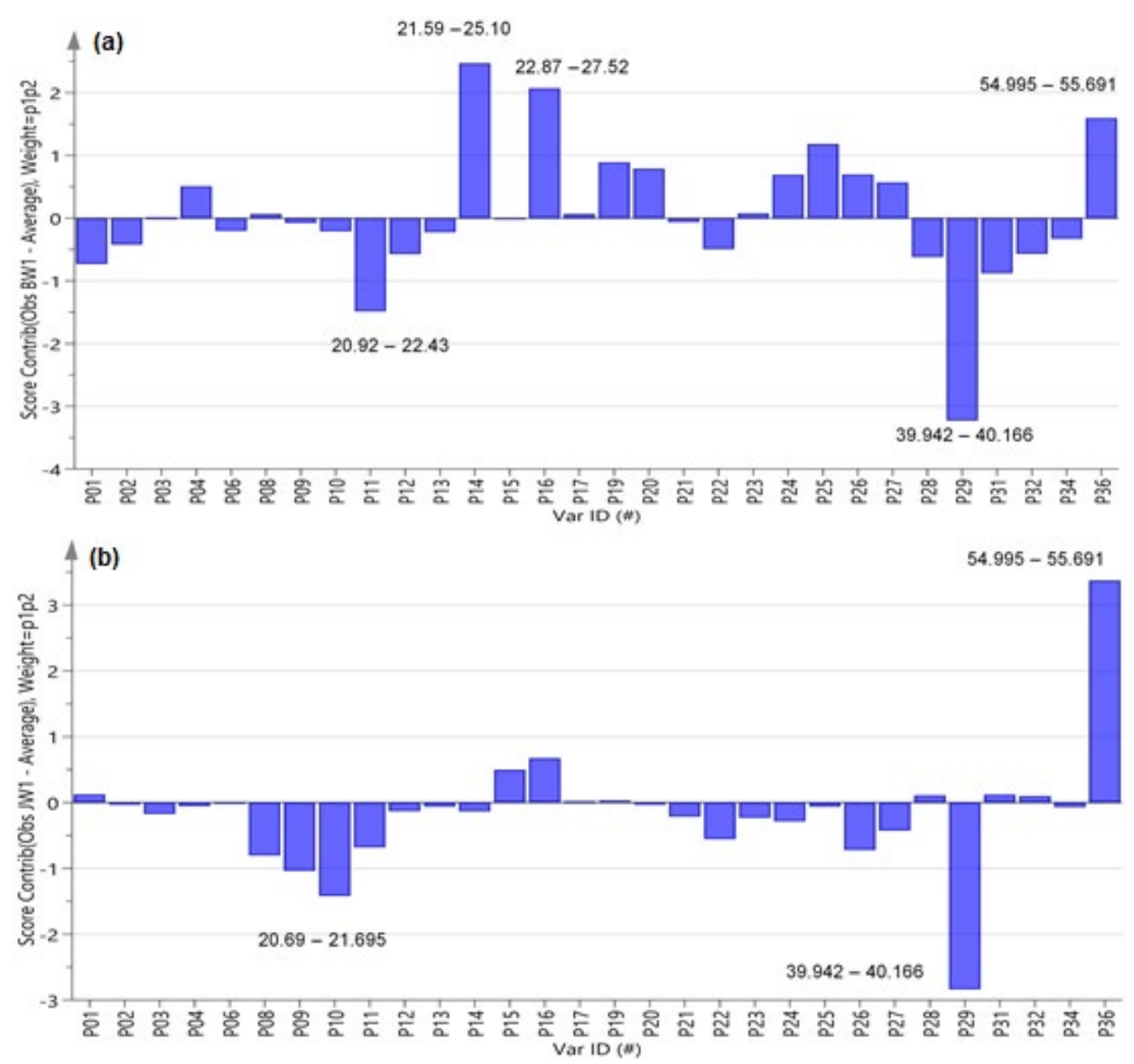

Fig 10. Two representative contribution plots of PCA Yacon HPLC data. (a) Contribution plot of Yacon water extract (Sample from Lembang Jawa Barat) and (b) Contribution plot of Yacon water extract from Wonosobo Jawa Tengah. Retention times mentioned in each figure representing metabolites were found to be more abundant in the associated extract if it is positioned above the $\mathrm{X}$-axis. Oppositely, it is found to be less abundant if it is positioned below the $\mathrm{X}$ axis. For example, Yacon water extract from Lembang contained peak at a retention time of 21.59-25.10 min with higher intensity, but it contained peak at a retention time of 20.92-22.43 min with lower intensity

No reports have been found regarding the identification of metabolites which discriminates Yacon leaves from different locations or extracted with different solvents. Thus, we could not compare the FTIR data obtained in this study with the data from the previous report. The commercially available compounds isolated from this plant is also not available. This is a hurdle of this research which hampers the identification of metabolites important for the separation. For a holistic view of this interaction, further research using a more robust tool such as NMR or LC-MS is recommended to disclose which compounds are represented by these discriminating peaks. We are currently conducting LCMS based metabolomics of the Yacon's extract to further identify these metabolites markers.

\section{- CONCLUSION}

The results of this study showed that FTIR and HPLC - Based Metabolomics supported by Principal Component Analysis (PCA), that was performed in 
order to capture and discern the unique geographical origin of Yacon leaves and its accompanying solvent characteristics for extraction, would have been difficult to do just through direct visual observation and comparison. Notably, FTIR was able to distinctly cluster Yacon samples based on the solvents, but it was not capable to classify them based on their geographical origins. However, HPLC was able to distinctly cluster Yacon samples based on both the solvents and geographical origins. Demonstration of such capability can be used to construct hypothesis and evaluation for future researches, as regards to the metabolites compound variations on the activity of samples, e.g. anti-inflammatory activity or antidiabetic activity, which can be evaluated through the combination of FTIR/HPLC and PCA for investigation.

\section{- ACKNOWLEDGMENTS}

The authors gratefully acknowledge the Faculty of Pharmacy, University of Pancasila, Jakarta for providing the HPLC and other laboratory facilities required for this study and the Laboratory of Tropical Biopharmaca Study Center IPB Bogor for providing the FTIR.

\section{- REFERENCES}

[1] Grau, A., and Rea, J., 1997, "Yacon. Smallanthus sonchifolius (Poepp. \& Endl.) H. Robinson" in Andean roots and tubers: Ahipa, arracacha, maca and yacon. Promoting the conservation and use of underulitized crops. 21, Eds. Hermann, M., and Heller, J., IPK \& Gatersleben/International Plant Genetic Resources Institute, Rome, Italy, 203-204, 209, 221-223, 230.

[2] Genta, S.B., Carbrera, W.M., Mercado, M.I., Grau, A., Catalán, C.A., and Sánchez, S.S., 2010, Hypoglycemic activity of leaf organic extracts from Smallanthus sonchifolius: Constituents of the most active fractions, Chem. Biol. Interact., 185, 143-152.

[3] Oliveira, R.B., Chagas-Paula, D.A., Secatto, A., Gasparoto, T.H., Faccioli, L.H., Campanelli, A.P., and Da Costa, F.B., 2013, Topical anti-inflammatory activity of yacon leaf extracts, Rev. Bras. Farmacogn., 23 (3), 497-505.

[4] Djamil, R., Winarti, W., Simanjuntak, P., and Syamsudin, 2014, Standardization and $\alpha$-glycosidase inhibition of extracts of Vatica pauciflora Blume stem barks and Smallanthus sonchifolius leaves, J. Pharmacogn. Phytochem., 3 (4), 42-46.

[5] Honoré, S.M., Genta, S.B and Sánchez, S.S., 2015, Smallanthus sonchifolius (Yacon) leaves an emerging source of compounds for diabetes management, $J$. Res. Biol., 5 (A), 021-042.

[6] Valentová, K., and Ulrichová, J., 2003, Smallanthus sonchifolius and Lepidium meyenii - Prospective Andean crops for the prevention of chronic diseases, Biomed. Pap., 147 (2), 119-130.

[7] Russo, D., Valentão, P., Andrade, P.B., Fernandez, E.C., and Milella, L., 2015, Evaluation of antioxidant, antidiabetic and anticholinesterase activities of Smallanthus sonchifolius landraces and correlation with their phytochemical profiles, Int. J. Mol. Sci., 16, 17696-17718.

[8] Soekarto, S.T., 2008, Penilaian organoleptik untuk industri pangan dan hasil pertanian, Bhratara Karya Aksara, Jakarta, 34.

[9] Juliani, Yuliana, N.D., Budijanto, S., Wijaya. C.H., and Khatib, A., 2016, Senyawa inhibitor aglukosidase dan antioksidan dari kumis kucing dengan pendekatan metabolomik berbasis FTIR, JTIP, 27 (1), 17-30.

[10] Edi, D.P., Rafi, M., Utami, D.S., Nurcholis, W., and Agung, M., 2014, Identifikasi dan autentikasi jahe merah menggunakan kombinasi spektroskopi FTIR dan kemometrik, Agritech, 34 (1), 82-87.

[11] Feng, X., Kong, W., Wei, J., Ou-Yang, Z., and Yang, M., 2013, HPLC fingerprint analysis combined with chemometrics for pattern recognition of ginger, $J$. Pharm. Biol., 52 (3), 362-367.

[12] Skoog. D.A., Holler. F.J., and Crounch. S.R., 2007, Principles of Instrumental Analysis, $6^{\text {th }}$ Ed., Thomson Brooks/Cole, Belmont, CA.

[13] Sun, X., Wang, H., Han, X., Chen, S., Zhu, S., and Dai, J., 2014, Fingerprint analysis of polysaccharides from different Ganoderma by HPLC combined with chemometrics methods, Carbohydr. Polym., 114, 432-439.

[14] Maser, W.H., Rusmarilin, H., and Yuliana, N.D., 2017, Aplikasi metabolomik berbasis HPLC untuk 
mengidentifikasi waktu retenasi komponen antibakteri Staphylococcus aureus pada ekstrak bunga kecombrang (Etlingera elatior), Alchemy, 13 (2), 241-251.

[15] Tahir, H.E., Xiaobo, Z., Zhihua, L., Jiyong, S., Zhai, X., Wang, S., and Mariod, A.A., 2017, Rapid prediction of phenolic compounds and antioxidant activity of Sudanese honey using Raman and Fourier transform infrared (FT-IR) spectroscopy, Food Chem., 226, 202-211.

[16] Isomaa, K., 2013, Chemometric Methods in Plant Metabolomic, Thesis, University of Helsinki.

[17] Silverstein, R.M., Bassler, G.C., and Morrill, T.C., 1981, Spectrometric Identification of Organic Compounds, $4^{\text {th }}$ Ed., John Wiley \& Sons, Inc., New York.

[18] Pomerantsev, A.L., 2014, Chemometric in Excel, John Wiley \& Sons, Inc., Hoboken, New Jersey.

[19] Dejaegher, B., Alaerts, G., and Matthijs, N., 2010, Methodology to develop liquid chromatographic fingerprints for the quality control of herbal medicines, Acta Chromatogr., 22 (2) 237-258.

[20] Khanmohammadi, M., 2015, Current Applications of Chemometric, Nova Science Publishers, Inc., Hauppauge, NY.

[21] Miller, J.N., and Miller, J.C., 2010, Statistics and Chemometrics for Analytical Chemistry, $6^{\text {th }}$ Ed., Pearson Education Limited, Prentice Hall, UK.

[22] Rafi, M., Rohaeti, E., Miftahudin, A., and Darusman, L.K., 2011, Differentiation of Curcuma longa,
Curcuma xanthorrhiza and Zingiber cassumunar by thin layer chromatography fingerprint analysis, Indones. J. Chem., 11 (1), 71-74.

[23] Levandi, T., Püssa, T., Vaher, M., Ingver, A., Koppel, R., and Kaljurand, M., 2014, Principal component analysis of HPLC-MS/MS patterns of wheat (Triticum aestivum) varieties, Proc. Est. Acad. Sci., 63 (1), 86-92.

[24] Valentová, K., Lebeda, A., Doležalová, I., Jirovský, D., Simonovska, B., Vovk, I., Kosina, P., Gasmanová, N., Dziechciarková, M., and Ulrichová, J., 2006, The biological and chemical variability of yacon, J. Agric. Food Chem., 54 (4), 1347-1352.

[25] Liang, Y.Z., Xie, P., Chan, K., 2004, Quality control of herbal medicines, J. Chromatogr. B, 812 (1-2), 53-70.

[26] Yongyu, Z., Shujun, S., Jianye, D., Wenyu, W., Huijuan, C., Jianbing, W., and Xiaojun, G., 2011, "Quality control method for herbal medicineChemical fingerprint analysis" in Quality Control of Herbal Medicines and Related Areas, IntechOpen, Rijeka, Croatia.

[27] Barbara, M.M., and Nossar, R., 2015, Peluang usaha: Budidaya tanaman obat diabetes mudah, tanam saja di tempat lembab, http://www.tribunnews.com/ bisnis/2015/09/03/peluang-usaha-budidaya-tanam an-obat-diabetes-mudah-tanam-saja-di-tempat-lem bab, accessed on 21 March 2016. 